\section{Biosynthesis of Nanoparticles - A New Horizon in Fish Biomedicine}

\author{
Pani Prasad Kurcheti ${ }^{1 *}$, Dhayanath ${ }^{1}$, Abisha Juliet Mary ${ }^{1}$, Jeena \\ and Hina Alim ${ }^{2}$
}

${ }^{1}$ Department of Aquatic Environment and Health Management, ICAR-Central Institute of Fisheries Education, Mumbai, India

${ }^{2}$ Department of Life Sciences, University of Mumbai, Vidyanagari Campus, Santacruz East, Mumbai, India

\begin{abstract}
The biogenic nanoparticle has becoming a significant potential technology as the result of phytomining which revealed that metals are usually deposited in the form of nanoparticles. The various biological agents in the form of algae, plants and microbes have emerged as an efficient candidate for the synthesis of nanoparticles. These biogenic nanoparticles involve producing biomolecules from plant extracts to reduce metal ions to nanoparticlesand it is cost efficient, simpler to synthesize. As this process use water soluble plant metabolites for nanoparticle production, this serves a perfect environmental friendly method which is an added advantage. This greener approach in nanoparticle production against fish pathogens can become an asset for the future aquaculture industry as it serves as a potential alternative to antibiotics which leads a sustained infection - free environment which is the impossible dream for many aquaculturists.
\end{abstract}

\section{Introduction}

Nanoscience will leave no field untouched by its ground breaking technical innovations but so far the use of nanoscience in fisheries has been predominantly theoretical. Nanoparticles are clusters of atoms in the size of $1-100 \mathrm{~nm}$. Due to large surface area to volume ratio these metallic NPs are known to possess remarkable antimicrobial properties by inducing the production of reactive oxygen species such as hydrogen peroxide. Nowadays, a wide variety of nanotechnological *Corresponding author: Pani Prasad Kurcheti, Department of Aquatic Environment and Health Management, ICAR-Central Institute of Fisheries Education, Mumbai, India, Tel: +91 9867241101; E-mail: kpaniprasad@cife.edu.in

Citation: Kurcheti PP, Dhayanath, Mary AJ, Jeena, Alim H (2020) Biosynthesis of Nanoparticles - A New Horizon in Fish Biomedicine. J Aquac Fisheries 4: 035.

Received: October 26, 2020; Accepted: December 28, 2020; Published: December 31, 2020

Copyright: ( 2020 Kurcheti PP, et al. This is an open-access article distributed under the terms of the Creative Commons Attribution License, which permits unrestricted use, distribution, and reproduction in any medium, provided the original author and source are credited. applications were arising for the infectious disease treatment which involves micro emulsions, vaccines and metallic, inorganic, lipid and polymeric - based nanoparticles. There were two important metal nanoparticles which were gold and silver nanoparticles [1]. The conclusion of various researches has been shown that among those different NPs; silver NPs shows strong inhibitory and microbicidal activity whereas it exhibits lower toxicity tomammalian cells. It was observed that, there has been emerging advancement in researches on nanoparticles which has lot of scope such as production of burn dressings, scaffolds, water purification systems, antimicrobial applications and medical devices. As this chemical method of nanoparticles production has been becoming the raising concernamong the environmentalists due to their adverse effect on ecology, the use of plant extracts for nanoparticles production is being recommended due its healthy nature towards the environment. Even in the industry it produces much lesstoxic waste. So this bionanotechnology, combines biological principles with physical and chemical approaches to produce nano-sized particles with specific functions. Various plant metabolites such as terpenoids, polyphenols, sugars, alkaloids, phenolic acids, and proteins, play an important role in the bio reduction of the metal ions. This article mainly focuses on this emerging green synthesis of nanoparticles with respect to fish medicine applications $[2,3]$.

\section{Different Approaches to Nanofabrication}

For nanofabrication, there followed two common procedures which were top - down and bottom - up approach. Assembling individual atoms and molecules to form nanoparticle describes bottom up approach and top-down approach involves fragmenting material to yield a nanoparticle described below in the figure 1.

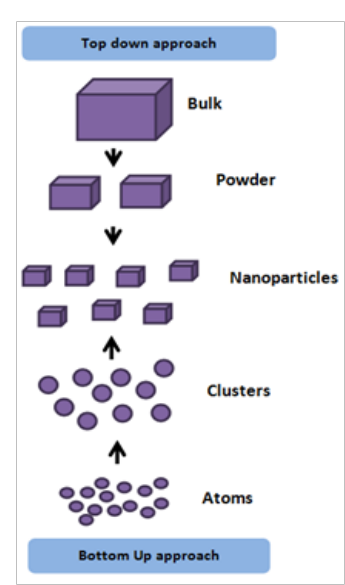

Figure 1: Approaches to Nanofabrication.

\section{Synthesis Methods}

There were 3 common methods for synthesizing nanoparticles which were described below in the figure 2 . 


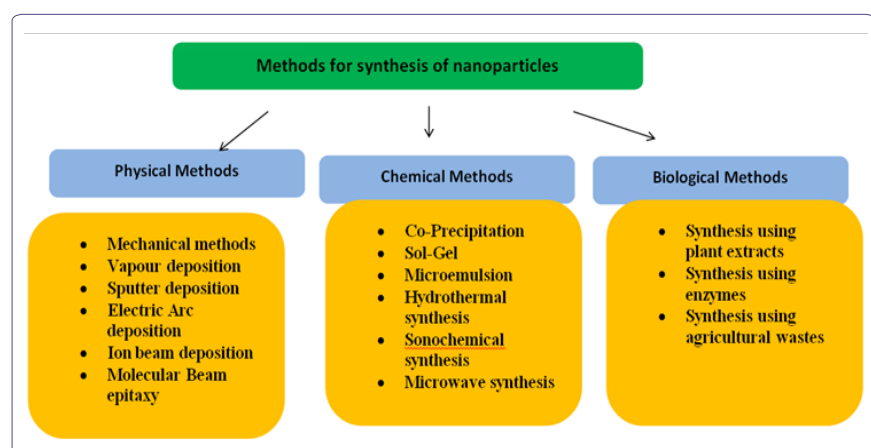

Figure 2: Methods for synthesizing nanoparticles.

Among the above described methods, the physical method of synthesizing is time and energy consuming and this involves synthesis at high temperature and pressure. The chemical method is simple and inexpensive and lowtemperature synthesis method, use of toxic reducing and stabilizing agents makes it harmful. The most important green synthesis of nanoparticles were easy, efficient and eco-friendly and this method eliminates the use of toxic chemicals, consume lessenergy and produce safer products and by products. The NPs synthesized in plant extracts already have a functionalized surface that can contain the organic ligands, proteins, polysaccharides and polyatomic alcohols that are absent in NPs synthesized using physical and chemical methods and this proves as a new platform in developing efficient nanoparticles which is recommended more.

\section{Green Synthesis}

The formation of nanoparticles usingplant extracts has become a major head start method in terms of its interaction and effect on theenvironment; it is completely environmentally friendly and does not pose any threats even from itswaste. During the process production of metal nanoparticles, the plant extract is simply mixed with a solution of metal salt at room temperature (Figure 3). It is a quick reaction and usually takes only minutes to complete. The developed nanoparticle properties and production time depend on various characteristics of plant extract, namely:

- Its concentration,

- The concentration of the metal salt,

- The $\mathrm{pH}$,

- Temperature; and

- Contact time

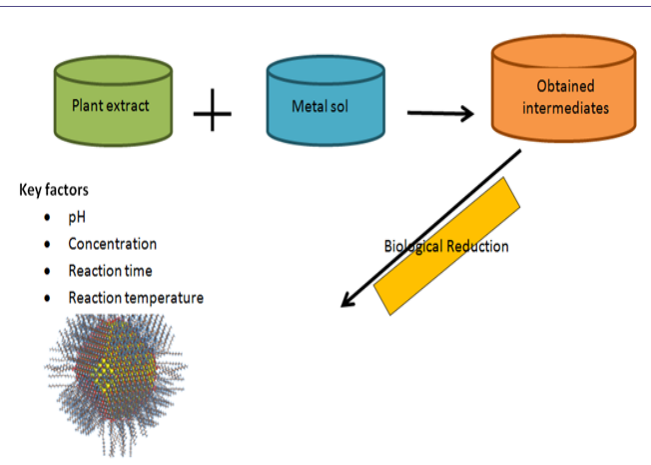

Figure 3: Nanoparticle properties and production time depend on various characteristics of plant extract.
Various plant extracts were used for this green nanoparticle synthesize which are, aloe vera, neem, tea leaves, lemongrass, coriander, cinnamon, gooseberry, ginger, eucalyptus, hydrilla, sea weeds, mangrove plant extracts, hibiscus, latex, mint, tulsi, banana, lotus etc...

\section{Antibacterial Activity against Fish Pathogens}

The mechanism of nanoparticles on bacteria are not fully elucidated, the three most common mechanism of toxicity proposed up to now be as follows.

\section{- Uptake of free silver ions followed by disruption \\ - Formation of reactive oxygen species}

- Direct damage to cell membranes

The applications of nanoparticles in aquaculture has promisingly seen in water quality improvement, aquatic animal nutrition, drug delivery, disease diagnosis and management but very few works has been done in the greener approach as it is forming a new horizon in the aquaculture era. Moreover, several reports are availablewhich have shown that AgNPs are effective against pathogenic organism namely B.subtilis, Vibrio cholerae, E.coli and reported that Ag NPs with larger surface area provide a better contact with microorganisms. Biogenic Ag-NP using tea leaf extract (Camellia sinensis) showed bactericidal activity against Vibrio harveyi in juvenile Feneropenaeus indicus, but only at high doses of the nanoparticles. The nanoparticles with leaves of Mangiferaindica (mango), Eucalytusterticonis, Carica Papaya and Musa paradisiacal (banana) plants has developed and tested against Aeromonahydrophila. Among them, synthetized nanoparticles with Carica papaya (papaya) show antimicrobial activity with $153.6 \mu \mathrm{g} \mathrm{mL}-1$ concentration. In 2015, research on biogenic $\mathrm{CuO}$ NPs shows enhanced antibacterial activity against all the fish pathogens even at lower concentrations, i.e. above $20 \mathrm{mu}$ g/ $\mathrm{mL}$, which was tested against Aeromonas hydrophila, Pseudomonas fluorescens and Flavobacterium branchiophilum. Further research in 2016 [4], the AgNPs application, using as reductor agent Azadirachta indica were used to evaluate the immune modular effect in infected mirgal with Aeromona hydrophila. Further works on antimicrobial activity of Leucas aspera-engineered silver nanoparticles against A. hydrophilainfections were done in catla. In-vivo analysis of biochemical parameters and histological architecture provided evidence for the antibacterial effect of silver nanoparticles in catla. Moreover, broth of Aloe leaf extract was used for green synthesis of Zinc Oxide Nanoparticles (ZnO-NPs), which showed higher bactericidal activity against A.hydrophilla. Leaf bud extractfrom mangrove Rhizophora mucronata for biological synthesis of AgNPs, then demonstrated antimicrobial effects against Pseudomonas fluorescens, Proteus species and Flavobacterium species. The brief discussion on the recent researches on the green nanoparticle applications in fish antibacterial activity described aboveis given in the table below [5]. This green approach in the fish medication of nanoparticles is shown to be a perfect therapy in future if researches have taken seriously in aquaculture industry (Table 1). 


\begin{tabular}{|c|c|c|}
\hline AgNPs characteristics & Microorganisms & Authors \\
\hline $\begin{array}{l}\text { Synthetized nanoparticles with leaves of Mangifera indica, Eucalytus terticonis, } \\
\text { Carica Papaya and Musa paradisiaca plants }\end{array}$ & Aeromona hydrophila & Mahanty, et al. [6] \\
\hline Green synthesized $\mathrm{CuO}$ & $\begin{array}{c}\text { Aeromonas hydrophila, Pseudomonas fluorescens and } \\
\text { Flavobacterium branchiophilum }\end{array}$ & Swain, et al. [7] \\
\hline AgNPs using Azadirachta indica & Aeromona hydrophila & Rather, et al. [8] \\
\hline Leucas aspera-engineered AgNPs & Aeromona hydrophila & Antony, et al. [9] \\
\hline AgNP using leaf bud extract from mangrove Rhizophora mucronata & $\begin{array}{c}\text { Pseudomonas fuorescens, Proteus species and Flavo- } \\
\text { bacterium } s p\end{array}$ & Umashankari, et al. [10] \\
\hline AgNP using tea leaf extract & Vibrio harveyi & Vaseeharan, et al. [11] \\
\hline ZnO-NPs using Aloe leaf extract & Aeromona hydrophila & Gunalan, et al. [12] \\
\hline
\end{tabular}

Table 1: Green nanoparticle application against fish pathogens [13,14].

\section{Conclusion}

Current research in biosynthesis of nanometals using plant extracts has opened a new era in fast and nontoxic methods for production of nanoparticles. Different methods (physical, chemical and biological) have beendeveloped to obtain NPs of various shapes and sizes. Among that this biological method of NPs is economically and environmentallyfriendly alternative to chemical and physical approaches. But the exact mechanism of synthesis of biogenic nanoparticles needs to be worked out.Based upon the above discussions it can be said that the synthesis of green nanoparticles may serve as a future direction in fish biomedical nanotechnology in developing antimicrobial compounds that are still to be explored.

\section{Acknowledgement}

The authors thank the Director, ICAR-CIFE for providing help in writing this review.

\section{References}

1. Sondi I, Salopek-Sondi B (2004) Silver nanoparticles as antimicrobial agent: A case study on E.coli as a model for Gram-negative bacteria. Journal of Colloid and Interface Science 275: 177-182.

2. Prakash P, Gnanaprakasam P, Emmanuel R, Arokiyaraj S, Saravanan M (2013) Green synthesis of silver nanoparticles from leaf extract of Mimusops elengi, Linn. for enhanced antibacterial activity against multi drug resistant clinical isolates. Colloids and Surfaces B: Biointerfaces 108: 255259.

3. Saxena A, Tripathi RM, Zafar F, Singh P (2012) Green synthesis of silver nanoparticles using aqueous solution of Ficus benghalensis leaf extract and characterization of their antibacterial activity. Materials letters 67: 91-94.

4. Ahmed S, Saifullah, Ahmad M, Swami BL, Ikram S (2016) Green synthesis of silver nanoparticles using Azadirachta indica aqueous leaf extract. Journal of radiation research and applied sciences 9: 1-7.

5. Singh K, Panghal M, Kadyan S, Chaudhary U, Yadav JP (2014) Antibacterial activity of synthesized silver nanoparticles from Tinospora cordifolia against multi drug resistant strains of Pseudomonas aeruginosa isolated from burn patients. Journal of Nanomedicine \& Nanotechnology 5: 1-6.
6. Mahanty A, Mishra S, Bosu R, Maurya UK, Netam SP, et al. (2013) Phytoextracts-synthesized silver nanoparticles inhibit bacterial fish pathogen Aeromonas hydrophila. Indian journal of microbiology 53: 438-446.

7. Swain P, Nayak SK, Sasmal A, Behera T, Barik SK, et al. (2014) Antimicrobial activity of metal based nanoparticles against microbes associated with diseases in aquaculture. World Journal of Microbiology and Biotechnology 30: 2491-2502.

8. Rather MA, Sharma R, Aklakur M, Ahmad S, Kumar N, et al. (2011) Nanotechnology: A novel tool for aquaculture and fisheries development. A prospective mini-review. Fisheries and Aquaculture Journal 16: 1-5.

9. Antony JJ, Nivedheetha M, Siva D, Pradeepha G, Kokilavani P, et al. (2013) Antimicrobial activity of Leucas aspera engineered silver nanoparticles against Aeromonas hydrophila in infected Catla catla. Colloids Surf B: Biointerfaces 109: 20-24.

10. Umashankari J, Inbakandan D, Ajithkumar TT, Balasubramanian T (2012) Mangrove plant, Rhizophora mucronata (Lamk, 1804) mediated one pot green synthesis of silver nanoparticles and its antibacterial activity against aquatic pathogens. AquatBiosyst 8: 11.

11. Vaseeharan B, Ramasamy P, Chen JC (2010) Antibacterial activity of silver nanoparticles (AgNps) synthesized by tea leaf extracts against pathogenic Vibrio harveyi and its protective efficacy on juvenile Feneropenaeus indicus. Lett ApplMicrobiol 50: 352-356.

12. Gunalan S, Sivaraj R, Rajendran V (2012) Green synthesized ZnO nanoparticles against bacterial and fungal pathogens. Prog Nat Sci Mater Int 22: 693-700.

13. Song JY, Kim (2009) Rapid biological synthesis of silver nanoparticles using plant leaf extracts. Bioprocess and biosystems engineering 32: 79.

14. Bandeira G, Sutili FJ, Gressler LT, Ely VL, Silveira BP, et al. (2018) Antibacterial potential of phytochemicals alone or in combination with antimicrobials against fish pathogenic bacteria. Journal of applied microbiology 125 : 655-665. 


\section{Hif}

Advances In Industrial Biotechnology | ISSN: 2639-5665

Advances In Microbiology Research | ISSN: 2689-694X

Archives Of Surgery And Surgical Education | ISSN: 2689-3126

Archives Of Urology

Archives Of Zoological Studies | ISSN: 2640-7779

Current Trends Medical And Biological Engineering

International Journal Of Case Reports And Therapeutic Studies | ISSN: 2689-310X

Journal Of Addiction \& Addictive Disorders | ISSN: 2578-7276

Journal Of Agronomy \& Agricultural Science | ISSN: 2689-8292

Journal Of AIDS Clinical Research \& STDs | ISSN: 2572-7370

Journal Of Alcoholism Drug Abuse \& Substance Dependence | ISSN: 2572-9594

Journal Of Allergy Disorders \& Therapy | ISSN: 2470-749X

Journal Of Alternative Complementary \& Integrative Medicine | ISSN: 2470-7562

Journal Of Alzheimers \& Neurodegenerative Diseases | ISSN: 2572-9608

Journal Of Anesthesia \& Clinical Care | ISSN: 2378-8879

Journal Of Angiology \& Vascular Surgery | ISSN: 2572-7397

Journal Of Animal Research \& Veterinary Science | ISSN: 2639-375

Journal Of Aquaculture \& Fisheries | ISSN: 2576-5523

Journal Of Atmospheric \& Earth Sciences | ISSN: 2689-8780

Journal Of Biotech Research \& Biochemistry

Journal Of Brain \& Neuroscience Research

Journal Of Cancer Biology \& Treatment | ISSN: 2470-7546

Journal Of Cardiology Study \& Research | ISSN: 2640-768X

Journal Of Cell Biology \& Cell Metabolism | ISSN: 2381-1943

Journal Of Clinical Dermatology \& Therapy | ISSN: 2378-8771

Journal Of Clinical Immunology \& Immunotherapy | ISSN: 2378-8844

Journal Of Clinical Studies \& Medical Case Reports | ISSN: 2378-880

Journal Of Community Medicine \& Public Health Care | ISSN: 2381-1978

Journal Of Cytology \& Tissue Biology | ISSN: 2378-9107

Journal Of Dairy Research \& Technology | ISSN: 2688-9315

Journal Of Dentistry Oral Health \& Cosmesis | ISSN: 2473-6783

Journal Of Diabetes \& Metabolic Disorders | ISSN: 2381-201X

Journal Of Emergency Medicine Trauma \& Surgical Care | ISSN: 2378-8798

Journal Of Environmental Science Current Research | ISSN: 2643-5020

Journal Of Food Science \& Nutrition | ISSN: 2470-1076

Journal Of Forensic Legal \& Investigative Sciences | ISSN: 2473-733X

Journal Of Gastroenterology \& Hepatology Research | ISSN: 2574-2566
Journal Of Genetics \& Genomic Sciences | ISSN: 2574-2485

Journal Of Gerontology \& Geriatric Medicine | ISSN: 2381-8662

Journal Of Hematology Blood Transfusion \& Disorders | ISSN: 2572-2999

Journal Of Hospice \& Palliative Medical Care

Journal Of Human Endocrinology | ISSN: 2572-9640

Journal Of Infectious \& Non Infectious Diseases | ISSN: 2381-8654

Journal Of Internal Medicine \& Primary Healthcare | ISSN: 2574-2493

Journal Of Light \& Laser Current Trends

Journal Of Medicine Study \& Research | ISSN: 2639-5657

Journal Of Modern Chemical Sciences

Journal Of Nanotechnology Nanomedicine \& Nanobiotechnology | ISSN: 2381-2044

Journal Of Neonatology \& Clinical Pediatrics | ISSN: 2378-878X

Journal Of Nephrology \& Renal Therapy | ISSN: 2473-7313

Journal Of Non Invasive Vascular Investigation | ISSN: 2572-7400

Journal Of Nuclear Medicine Radiology \& Radiation Therapy | ISSN: 2572-7419

Journal Of Obesity \& Weight Loss | ISSN: 2473-7372

Journal Of Ophthalmology \& Clinical Research | ISSN: 2378-8887

Journal Of Orthopedic Research \& Physiotherapy | ISSN: 2381-2052

Journal Of Otolaryngology Head \& Neck Surgery | ISSN: 2573-010X

Journal Of Pathology Clinical \& Medical Research

Journal Of Pharmacology Pharmaceutics \& Pharmacovigilance | ISSN: 2639-5649

Journal Of Physical Medicine Rehabilitation \& Disabilities | ISSN: 2381-8670

Journal Of Plant Science Current Research | ISSN: 2639-3743

Journal Of Practical \& Professional Nursing | ISSN: 2639-568

Journal Of Protein Research \& Bioinformatics

Journal Of Psychiatry Depression \& Anxiety | ISSN: 2573-0150

Journal Of Pulmonary Medicine \& Respiratory Research | ISSN: 2573-0177

Journal Of Reproductive Medicine Gynaecology \& Obstetrics | ISSN: 2574-2574

Journal Of Stem Cells Research Development \& Therapy | ISSN: 2381-2060

Journal Of Surgery Current Trends \& Innovations | ISSN: 2578-7284

Journal Of Toxicology Current Research | ISSN: 2639-3735

Journal Of Translational Science And Research

Journal Of Vaccines Research \& Vaccination | ISSN: 2573-0193

Journal Of Virology \& Antivirals

Sports Medicine And Injury Care Journal | ISSN: 2689-8829

Trends In Anatomy \& Physiology | ISSN: 2640-7752

Submit Your Manuscript: https://www.heraldopenaccess.us/submit-manuscript 